\title{
Recent Books and Journals Articles in Public Opinion, Survey Methods, Survey Statistics, Big Data and User Experience Research. 2017 Update
}

Mario Callegaro*

Tags: user experience, public opinion, survey methods, survey statistics, big data

\section{Survey Practice}

Vol. 11, Issue 2, 2018

\begin{abstract}
Welcome to the 9th edition of this column on recent books and journal articles in the field of public opinion, survey methods, survey statistics, Big Data, and user experience research.

This article is an update of the 2016 article. Like the previous year, the books are organized by topic; this should help the readers to focus on their interests.

Given that the last update listed books available as of August 2016, I added few books, papers, and special issues that came out in late 2016, so there is no gap.
\end{abstract}

Welcome to the 9th edition of this column on recent books and journal articles in the field of public opinion, survey methods, survey statistics, Big Data, and user experience research.

This article is an update of the 2016 article. Like the previous year, the books are organized by topic; this should help the readers to focus on their interests.

Given that the last update listed books available as of August 2016, I added a few books, papers, and special issues that came out in late 2016, so there is no gap. This year I added a new section on user experience research. User experience research is a growing field with many applications to desktop and mobile platforms. Given almost all data collection methods in survey research rely heavily on technology, the learnings from the user experience field can be very beneficial to the survey researcher and practitioner.

You will also note that I use very broad definitions of public opinion, survey methods, survey statistics, Big Data, and user experience research. This is because there are many books published in different outlets that can very useful to the readers of Survey Practice, even if they do not come from traditional sources of survey content.

It is unlikely I have exhaustively listed all new books in each subcategory; I did my best scouting different resources and Websites, but I take full responsibility for any omission. The list is also focused only on books published in the English language and available for purchase (as an ebook or in print) at the time 
of this review (January 2018) and with copyright year as either 2016 or 2017. Books are listed based on the relevance to the topic, and no judgment is made in terms of quality of the content. We let the readers do so.

If you want to send information for the next issue, please send it to surveyprac tice.new.books@gmail.com

\section{JOURNALS - SPECIAL ISSUES}

Big Data published a special issue on "Computational Propaganda and Political Big Data". Volume 5, Issue 4, 2017.

The Journal of Official Statistics published a special issue on "Responsive and Adaptive Survey Design: Looking Back to See Forward". Volume 33, Issue 3, 2017.

The Journal of Official Statistics published a special issue on "Total Survey Error". Volume 33, Issue 2, 2017.

The Journal of Official Statistics published a special section on "The Role of Official Statistics in Statistical Capacity Building". Volume 32, Issue 4, 2016.

The Journal of Survey Statistics and Methodology published a special section on "Recreational Surveys". Volume 5, Issue 3, 2017.

Methods, Data and Analysis published a special issue on "Data Collection in Panel Surveys". Volume 11, Issue 1, 2017.

Public Opinion Quarterly published a special issue on "Survey Research, Today and Tomorrow". Volume 81, Issue S1, 2017.

Social Science Computer Review published a special issue on "Citizenship, Social Media, and Big Data". Volume 35, Issue 1, 2017.

Social Science Research published a special issue on "Big Data in the Social Sciences". Volume 59, 2016.

Sociological Methodology published a series of papers from the symposium on interviewing. Volume 46, Issue 1, 2016.

Sociological Methods $\sigma^{\circ}$ Research published a special issue on "Models for Three-Wave Panel Data: Examples Using the General Social Survey Panels". Volume 46, Issue 1, 2017.

Survey Research Methods published a special issue on "Uses of Geographic Information Systems Tools in Survey Data Collection and Analysis". Volume 11, Issue 3, 2017.

The ANNALS of the American Academy of Political and Social Science published a special issue on "The New Big Science: Linking Data to Understand People in Context". Volume 669, Issue 1, 2017. 
The ANNALS of the American Academy of Political and Social Science published a special issue on "Elections in America". Volume 661, Issue 1, 2016.

"Annual Reviews critically reviews the most significant primary research literature to guide researchers to the principal contributions of their field [...] Each article is its own search engine, providing a gateway to the essential primary research literature referenced within each topic" (from the Annual Reviews Website).

Relevant to our topics these are the reviews published recently:

Baldassarri, D. and M. Abascal. 2017. Field experiments across the social sciences. Annual Review of Sociology 43(1): 41-73.

Berinsky, A.J. 2017. Measuring public opinion with surveys. Annual Review of Political Science 20(1): 309-329.

Bollen, K.A., P.P. Biemer, A.F. Karr, S. Tueller and M.E. Berzofsky. 2016. Are survey weights needed? A review of diagnostic tests in regression analysis. Annual Review of Statistics and Its Application 3(1): 375-392.

Chandler, J. and D. Shapiro. 2016. Conducting clinical research using crowdsourced convenience samples. Annual Review of Clinical Psychology 12(1): 53-81.

Citro, C.F. 2016. The US federal statistical system's past, present, and future. Annual Review of Statistics and Its Application 3(1): 347-373.

Cook, D., E-K. Lee and M. Majumder. 2016. Data visualization and statistical graphics in Big Data analysis. Annual Review of Statistics and Its Application 3(1): 133-159.

Couper, M.P. 2017. New developments in survey data collection. Annual Review of Sociology 43(1): 121-145.

de la Cuesta, B. and K. Imai. 2016. Misunderstandings about the regression discontinuity design in the study of close elections. Annual Review of Political Science 19(1): 375-396.

Dunning, T. 2016. Transparency, replication, and cumulative learning: what experiments alone cannot achieve. Annual Review of Political Science 19(1): S1-S23.

Evans, J.A. and P. Aceves. 2016. Machine translation: mining text for social theory. Annual Review of Sociology 42(1): 21-50.

Freese, J. and D. Peterson. 2017. Replication in social science. Annual Review of Sociology 43(1): 147-165.

Gross, C. 2016. Scientific misconduct. Annual Review of Psychology 67(1): 693-711. 
Howe, L.C. and J.A. Krosnick. 2017. Attitude strength. Annual Review of Psychology 68(1): 327-351.

Judd, C.M., J. Westfall and D.A. Kenny. 2017. Experiments with more than one random factor: designs, analytic models, and statistical power. Annual Review of Psychology 68(1): 601-625.

Keller, S.A., S. Shipp and A. Schroeder. 2016. Does Big Data change the privacy landscape? A review of the issues. Annual Review of Statistics and Its Application 3(1): 161-180.

Lazer, D. and J. Radford. 2017. Data ex machina: introduction to Big Data. Annual Review of Sociology 43(1): 19-39.

Leek, J.T. and L.R. Jager. 2017. Is most published research really false? Annual Review of Statistics and Its Application 4(1): 109-122.

Wilkerson, J. and A. Casas. 2017. Large-scale computerized text analysis in political science: opportunities and challenges. Annual Review of Political Science: 20(1): 529-544.

\section{PUBLIC OPINION BOOKS}

Asher, H. 2017. Polling and the public: what every citizen should know (9th ed.). Sage, Thousand Oaks, CA.

Bennett, S.E. 2017. Applying public opinion in governance: the uses and future of public opinion in managing government. Springer, New York.

Bethlehem, J. 2017. Understanding public opinion polls. CRC Press, Boca Raton, FL.

Blais, A., J-F. Laslier and K. Van der Straeten (eds.). 2016. Voting experiments. Springer, New York.

Green, J. and W. Jennings. 2017. The politics of competence: parties, public opinion and voters. Cambridge University Press, Cambridge.

Norris, P. and A. Nai (eds.). 2017. Election watchdogs: transparency, accountability and integrity. Oxford University Press, Oxford.

\section{SURVEY METHODS BOOKS}

Baker, H.S. 2017. Evidence. Chicago University Press, Chicago.

Beins, B.C. 2017. Research methods: a tool for life (3rd ed.). Cambridge University Press, Cambridge.

Biemer, P.P., E. De Leeuw, S. Eckman, B. Edwards, F. Kreuter, L.E. Lyberg, N.C. Tucker and B.T. West (eds.). 2017. Total survey error in practice. Wiley, Hoboken, NJ. 
Boréus, K. and G. Bergström. 2017. Analyzing text and discourse: eight approaches for the social sciences. Sage, London.

Church, A.H. and J. Waclawski. 2017. Designing and using organizational surveys. Routledge, New York.

Cooper, H. 2016. Ethical choices in research: managing data, writing reports, and publishing results in the social sciences. American Psychological Association, Washington D.C.

Dawson, C. 2016. 100 activities for teaching research methods. Sage, Croydon, UK.

de Jonge, T., R. Veenhoven and W. Kalmijn. 2017. Diversity in survey questions on the same topic: techniques for improving comparability. Springer, New York.

Edwards, R., J. Goodwin, H. O'Connor and A. Phoenix (eds.). 2017. Working with paradata, marginalia and fieldnotes: the centrality of by-products of social research. Edward Elgar Publishing, Cheltenham, UK.

Fielding, N., R.M. Lee and G. Blank (eds.). 2017. The SAGE bandbook of online research methods (2nd ed.). Sage, London.

Gerring, J. and D. Christenson. 2017. Applied social science methodology: an introductory guide. Cambridge University Press, Cambridge.

Goertz, G. 2017. Multimethod research, causal mechanisms, and case studies: an integrated approach. Princeton University Press, Princeton, NJ.

Harrison, M., J., Cupman, O. Truman and P. Hague. 2016. Market research in practice: an introduction to gaining greater market insight. Kogan Page, London.

Hepburn, A. and G.B. Bolden. 2017. Transcribing for social research. Sage, Los Angeles, CA.

Iphofen, R. 2017. Finding common ground: consensus in research etbics across the social sciences. Vol. 1. Emerald Publishing, Bingley, UK.

Krabbe, P.F.M. 2017. The measurement of health and bealth status: concepts, methods and applications from a multidisciplinary perspective. Elsevier, London.

Laurent, É. 2017. Measuring tomorrow: accounting for well-being, resilience, and sustainability in the twenty-first century. Princeton University Press, Princeton, NJ.

Lauro, C., E. Amaturo, G.M. Grassia, B. Aragona and M. Marino (eds.). 2017. Data science and social research: epistemology, methods, technology and applications. Springer, New York. 
Martin, J.L. 2017. Thinking through methods: a social science primer. Chicago University Press, Chicago.

Lietz, P., J.C. Cresswell, K.F. Rust and R.J. Adams (eds.). (2017). Implementation of large-scale education assessments. Wiley, Hoboken, NJ.

Meltzoff, J. and H. Cooper. 2017. Critical thinking about research: psychology and related fields (2nd ed.). American Psychological Association, Washington D.C.

Mollett, A., C. Brumley, C. Gilson and S. Williams. 2017. Communicating your research with social media: a practical guide to using blogs, podcasts, data visualisations and video. Sage, London.

Morgan, S., T. Reichert and T.R. Harrison. 2017. From numbers to words: reporting statistical results for the social sciences. Routledge, New York.

O'Reilly, M. and N. Dogra. 2017. Interviewing children and young people for research. Sage, London.

Prior, J. and J. Van Herwegen (eds.). 2016. Practical research with children. Routledge, New York.

Schauf, R.W. 2016. Mixed methods: interviews, surveys, and cross-cultural comparisons. Cambridge University Press, New York.

Sprague, J. 2016. Feminist methodologies for critical researchers: bridging differences (2nd ed.). Rowman \& Littlefield, Lanham, MD.

Woodside, A.G. (ed.). 2016. Bad to good: achieving bigh quality and impact in your research. Emerald Group, Bingley, UK.

Wright, F.D. 2016. Researching developing countries: a data resource guide for social scientists. Elsevier, Waltham, MA

Zozus, M. 2017. The data book: collection and management of research data. CRC Press, Boca Raton, FL.

Zumbo, B.D. and A.M. Hubley (eds.). 2017. Understanding and investigating response processes in validation research. Springer, New York.

\section{SURVEY STATISTICS BOOKS}

Arnab, R. 2017. Survey sampling: theory and applications. Elsevier, San Diego.

Beins, B.C. and M.A. McCarthy. 2017. Research methods and statistics. Cambridge University Press, Cambridge.

Bohning, D., P.G.M. van der Heijden and J. Bunge (eds.). 2017. Capture-recapture methods for the social and medical sciences. Chapman and Hall, Boca Raton, FL. 
Chaudhuri, A. 2017. Randomized response and indirect questioning techniques in surveys. CRC Press, Boca Raton, FL.

Chaudhuri, A., T.C. Christofides and C.R. Rao (eds.). 2016. Data gathering, analysis and protection of privacy through randomized response techniques: qualitative and quantitative buman traits. Vol. 34. Elsevier, Amsterdam.

Cizek, G.J. and J.A. Wollack (eds.). 2017. Handbook of quantitative methods for detecting cheating on tests. Routledge, New York.

Dean, A., D. Voss, and D. Draguljić. Design and analysis of experiments. Springer, New York.

Gailmard, S. 2017. Statistical modeling and inference for social science. Cambridge University Press, Cambridge.

Greenacre, M. 2017. Correspondence analysis in practice (3rd ed.). CRC Press, Boca Raton, FL.

Hahs-Vaughn, D.L. 2017. Applied multivariate statistical concepts. Routledge, New York.

Hedberg, E.C. 2017. Introduction to power analysis: two-group studies. Sage, Thousand Oaks, CA.

Heeringa, S.G., B.T. West and P.A. Berglund. 2017. Applied survey data analysis (2nd ed.). CRC Press, Boca Raton, FL.

Hox, J.J., M. Moerbeek and R. van der Schoot. 2017. Multilevel analysis: techniques and applications (3rd ed.). Routledge, New York.

Islam, A.M. and R.I. Chowdhury. 2017. Analysis of repeated measures data. Springer, Singapore.

Judd, C.M., G.H. McClelland and C.S. Ryan. 2017. Data analysis: a model comparison approach to regression, ANOVA, and beyond (3rd ed.). Routledge, New York.

Kranzler, J.H. 2016. Statistics for the terrified (6th ed.). Rowman \& Littlefield, Lanham, MD.

Leite, W. 2017. Practical propensity score methods using $R$. Sage, Thousand Oaks, CA.

Levy, R. and R.J. Mislevy. 2016. Bayesian psychometric modeling. CRC Press, Boca Raton, FL.

Lewis, T.H. 2017. Complex survey data analysis with SAS. CRC Press, Boca Raton, FL.

Manly, B.F.J. and J.A. Navarro-Alberto. 2017. Multivariate statistical 
methods: a primer(4th ed.). CRC Press, Boca Raton FL.

McCleary, R., D. McDowall and B. Bartos. 2017. Design and analysis of time series experiments. Oxford University Press, Oxford.

Montgomery, D.C. 2017. Design and analysis of experiments (9th ed.). Wiley, Chichester, UK.

Morris, M. 2017. Design of experiments: an introduction based on linear models. CRC Press, Boca Raton, FL.

Price, L.R. 2017. Psychometric methods: theory into practice. Guilford Press, New York.

Salkind, N.S. 2016. Statistics for people who (think they) bate statistics (6th ed.). Sage, Thousand Oaks, CA.

Schouten, B., A. Peytchev and J. Wagner. 2017. Adaptive survey design. CRC Press, Boca Raton, FL.

Schroeder, L.D., D.L. Sjoquist and P.E. Stephan. 2017. Understanding regression analysis. an introductory guide (2nd ed.). Sage, Thousand Oaks, CA.

Scott, J. 2017. Social network analysis (4th ed.). Sage, London.

Templ, M. 2017. Statistical disclosure control for microdata: methods and applications in $R$. Springer, New York.

van der Linden, W.J. (2016). Handbook of item response theory: models. Vol. 1. CRC Press, Boca Raton, FL.

Wilcox, R. 2017. Modern statistics for the social and behavioral sciences: a practical introduction (2nd ed.). Chapman and Hall, Boca Raton, FL.

\section{BIG DATA, SOCIAL MEDIA AND OTHER RELEVANT BOOKS}

Cady, F. 2017. The data science handbook. Wiley, Hoboken, N.J.

Hai-Jew, S. (ed.). 2016. Social media data extraction and content analysis. IGI Global, Harrisburg, PA.

Ignatow, G. and R.F. Mihalcea. 2017. Text mining: a guidebook for the social sciences. Sage, Thousand Oaks, CA.

National Academies of Sciences, Engineering, and Medicine. 2017a. Federal statistics, multiple data sources, and privacy protection: next steps. National Academies Press, Washington D.C.

National Academies of Sciences, Engineering, and Medicine. 2017b. Innovations in federal statistics. Combining data sources while protecting privacy consensus study report. National Academies Press, Washington D.C. 
Peng, R.D., E. Matsui and C. Keet. 2017. The data science salon. A collaborative learning experience. Leanpub.

Ratner, B. 2017. Statistical and machine-learning data mining: techniques for better predictive modeling and analysis of big data (3rd ed.). CRC Press, Boca Raton, FL.

Sloan, L. and A. Quan-Haase (eds.). 2017. The SAGE handbook of social media research methods. Sage, London.

Stephens-Davidowitz, S. 2017. Everybody lies: Big Data, new data, and what the internet can tell us about who we really are. HarperCollins, New York.

Witten, I., E. Frank, M. Hall, and C. Pal. 2017. Data mining: practical machine learning tools and techniques. Morgan Kaufmann, Cambridge, MA.

\section{USER EXPERIENCE RESEARCH BOOKS}

Baines, J. and C. Howard. 2016. UX lifecycle: the business guide to implementing great software user experiences. CreateSpace Independent Publishing Platform.

Byrne, T. and J. Gingras. 2017. The right way to select technology: get the real story on finding the best fit. Rosenfeld Media, Brooklyn, New York.

Enders, J. 2016. Designing UX forms: design forms that won't drive users crazy. SitePoint, VIC, Australia.

Evans, D.C. 2017. Bottlenecks: aligning UX design with user psychology. Apress, Kenmore, WA.

Ferreira, A. 2016. Universal UX design: building multicultural user experience. Morgan Kaufmann, Cambridge, MA.

Geisen, E. and J. Romano Bergstrom. 2017. Usability testing for survey research. Morgan Kaufmann, Cambridge, MA.

Kalbach, J. 2016. Mapping experiences: a complete guide to creating value through journeys, blueprints, and diagrams. O'Reilly Media, Sebastopol, CA.

Vu K.P.L. and R.W. Proctor (eds.). 2017. Handbook of buman factors in web design. (2nd ed.). CRC Press, Boca Raton FL.

King, R., E.F. Churchill, and C. Tan. 2017. Designing with data: improving the user experience with $A / B$ testing. O'Reilly Media, Sebastopol, CA.

Lang, J. and E. Howell. 2017. Researching UX: user research. SitePoint, VIC, Australia.

Lazar, J., J. Feng and H. Hochheiser. 2017. Research methods in buman-computer interaction (2nd ed.). Morgan Kaufmann, Cambridge, MA. 
Lichaw, D. 2016. The user's journey: storymapping products that people love. Rosenfeld Media, Brooklyn, New York.

Nunnally, B. and D. Farkas. 2017. UX research: practical techniques for designing better products. O'Reilly Media, Sebastopol, CA.

Pannafino, J. and P. McNeil. 2017. UX methods: a quick guide to user experience research methods. CDUXP LLC.

Platt, D. 2016. The joy of UX: user experience and interactive design for developers. Addison-Wesley, Boston, MA.

Sauro, J. and J. Lewis. 2016. Quantifying the user experience: practical statistics for user research (2nd ed.). Morgan Kaufmann, Cambridge, MA.

Sharon, T. 2016. Validating product ideas through lean user research. Rosenfeld Media, Brooklyn, New York.

Szabo, P.W. 2017. User experience mapping: enhance UX with user story map, journey map and diagrams. Packt Publishing, Birmingham, UK.

Wiklund, M.E. P.E., J. Kendler, and A.Y. Strochlic. 2017. Usability testing of medical devices (2nd ed.). CRC Press, Boca Raton, FL. 